
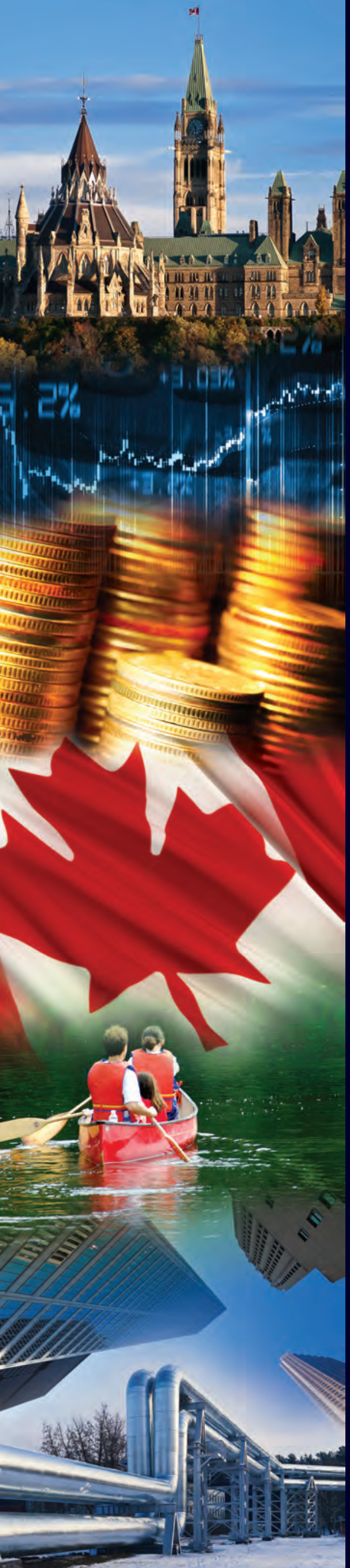

COMMENTARY

NO. 546

\title{
Over the Top: Why an Annual Wealth Tax for Canada is Unnecessary
}

From economist Thomas Piketty to Senator Elizabeth Warren, proponents of an annual wealth tax are giving the idea new life. Our authors assess whether it is a good idea for Canada - or not.

Robin Boadway and Pierre Pestieau 


\section{THE C.D. HOWE INSTITUTE'S COMMITMENT TO QUALITY, INDEPENDENCE AND NONPARTISANSHIP}

\section{ABOUT THE AUTHORS}

\section{Robin Boadway \\ OC, FRSC}

is Emeritus Professor of

Economics, Queen's University.

He was Head of the Department of Economics at Queen's from 1981-86, and President of the Canadian Economics Association, 1996-97.

Pierre Pestieau is Professor Emeritus, Université de Liège. He is associate editor of Journal of Public Economic Theory, CESifo Economic Studies and Annals of Public and Cooperative Economics.
Commentary No. 546

June 2019

Fiscal and Tax Policy
$\$ 12.00$

ISBN 978-1-989483-07-7

ISSN 0824-8001 (print);

ISSN 1703-0765 (online)
The C.D. Howe Institute's reputation for quality, integrity and nonpartisanship is its chief asset.

Its books, Commentaries and E-Briefs undergo a rigorous two-stage review by internal staff, and by outside academics and independent experts. The Institute publishes only studies that meet its standards for analytical soundness, factual accuracy and policy relevance. It subjects its review and publication process to an annual audit by external experts.

As a registered Canadian charity, the C.D. Howe Institute accepts donations to further its mission from individuals, private and public organizations, and charitable foundations. It accepts no donation that stipulates a predetermined result or otherwise inhibits the independence of its staff and authors. The Institute requires that its authors disclose any actual or potential conflicts of interest of which they are aware. Institute staff members are subject to a strict conflict of interest policy.

C.D. Howe Institute staff and authors provide policy research and commentary on a non-exclusive basis. No Institute publication or statement will endorse any political party, elected official or candidate for elected office. The views expressed are those of the author(s). The Institute does not take corporate positions on policy matters.
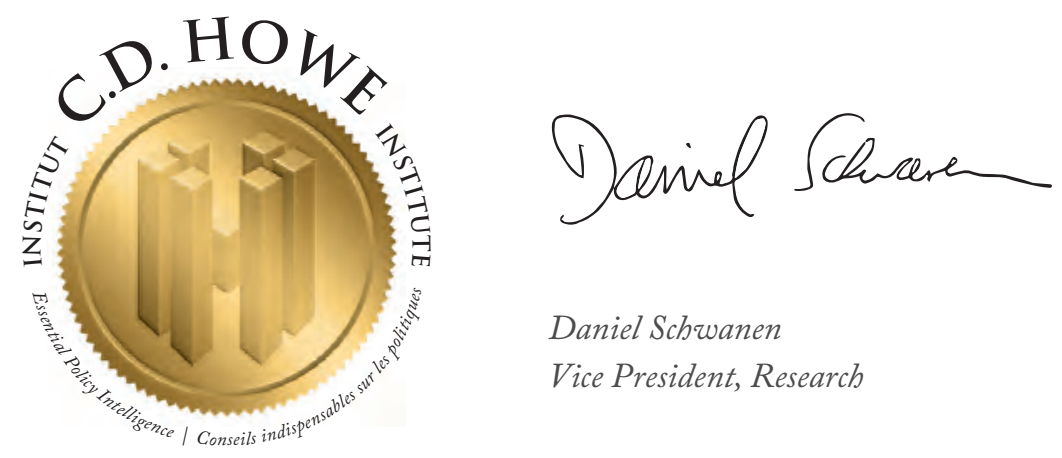

Daniel Schwanen

Vice President, Research 


\section{THE STUDY IN BRIEF}

The idea of a wealth tax has taken on new prominence since French economist Thomas Piketty famously proposed a global wealth tax in 2013; Senator Elizabeth Warren has even made a national wealth tax a plank in her campaign to become the Democratic presidential candidate in 2020.

The current interest in wealth taxation is a response to the increase in wealth concentration and income inequality that has occurred in most OECD countries. It has been well documented that both income and wealth inequality have risen significantly in recent decades.

In this Commentary, we critically evaluate the case for an annual wealth tax as part of Canada's tax system. To do so, we review current received wisdom on the elements of a good tax system, drawing on the normative tax design literature and best practices. We do not address the issue of how responsive tax policy needs to be to deal with the evolving inequality of income and wealth. Our focus, instead, is on the mix of policy instruments that are most effective for whatever degree of responsiveness policymakers choose.

Our argument is that wealth taxes add relatively little to the taxes on capital and capital income that are already in place, and that concerns about the social consequences of wealth concentration are better addressed by reform of existing capital income taxes and by considering wealth transfer (inheritance) taxation.

Our argument against wealth taxation is over and above the substantial administrative challenges in measurement, collection and coverage for annual wealth taxes. These alone are enough to raise red flags about wealth taxation. For our part, we rely on the more fundamental argument that annual net wealth taxes are unnecessary since their objectives can be better achieved by suitably designed taxes on capital income and wealth transfers.

C.D. Howe Institute Commentary $($ is a periodic analysis of, and commentary on, current public policy issues. Michael Benedict and James Fleming edited the manuscript; Yang Zhao prepared it for publication. As with all Institute publications, the views expressed here are those of the authors and do not necessarily reflect the opinions of the Institute's members or Board of Directors. Quotation with appropriate credit is permissible.

To order this publication please contact: the C.D. Howe Institute, 67 Yonge St., Suite 300, Toronto, Ontario M5E 1J8. The full text of this publication is also available on the Institute's website at www.cdhowe.org. 


\section{The idea of an annual tax on net wealth has recently gained prominence.}

French economist Thomas Piketty (2013) famously proposed a global wealth tax to address what he saw as an unacceptable increase in the concentration of riches among the wealthiest individuals, especially among Organisation of Economic Cooperation and Development (OECD) countries. More recently, the idea of a national wealth tax has been taken up by Massachusetts senator Elizabeth Warren as a key part of her policy platform in the quest to be the 2020 Democratic presidential candidate. She proposes a national wealth tax of 2 percent per year on Americans with more than $\$ 50$ million in assets, rising to 3 percent for those with at least $\$ 1$ billion. For their part, US academics Saez and Zucman (2019) provide a sympathetic summary of the arguments for wealth taxation. While a wealth tax has not been on the Canadian tax reform agenda, it is worth asking whether it should be.

The current interest in wealth taxation is a response to the increase in wealth concentration and income inequality that has occurred in most OECD countries. It has been well documented that both income and wealth inequality have risen significantly in recent decades (OECD 2018b, World Inequality Report 2018, Zucman 2019). The increase in the share of income earned by the top 1 percent has been particularly pronounced, as Piketty and Saez (2003) have documented. ${ }^{1}$ Canada has not been immune from these trends (Frenette, Green and Milligan 2007). Piketty (2013) argues that these inequalities are attributable to a tendency for the rate of return on capital to exceed productivity growth rates and, therefore, wages. The result is that the share of capital relative to labour income has been growing and, given that capital income accrues disproportionately to more affluent persons, this leads to a growth in income and wealth inequality.

Furthermore, the increasing concentration of wealth is exacerbated to the extent that the rate of return on capital rises with portfolio size (Fagereng et al. 2016, Kacperczyk, Van Nieuwerburgh, and Veldkamp 2016). Piketty also finds that the proportion of savings devoted to the creation of inheritances rather than to life-cycle smoothing has increased, and this reduces intergenerational mobility and equality of opportunity for those unable to inherit such great wealth.

Meanwhile, after-tax income inequality has grown even more rapidly than pre-tax income inequality as national tax systems have become less progressive. Income tax rate structures have become flatter, and capital income tax rates have dropped as nations compete for investors. Some countries have introduced a system of dual taxation whereby personal taxes on capital incomes were lowered relative to personal taxes on labour income.

As well, the average OECD statutory corporate income tax rate has declined from 47 percent in 1981 to 25 percent in 2013 (although corporate taxes as a share of GDP have remained relatively stable,

This paper develops for the Canadian case some ideas found in Boadway and Pestieau (2018). We are grateful to Alexandre Laurin, Kevin Milligan, anonymous reviewers, and members of the C.D. Howe Institute's Fiscal and Tax Policy Council for helpful comments on an earlier draft. The authors retain responsibility for any errors and the views expressed.

1 Income shares were calculated using taxable income recovered from US Internal Revenue Source records. Larrimore et al. (2017) show that when income shares are based on comprehensive income, including accrued capital gains, the share of the top 1 percent increases much less rapidly. 
reflecting the fact that corporate tax bases have been broadening). Taxes on dividend income fell from 75 percent to 42 percent during the same period.

Furthermore, realized capital gains are concentrated among those at the top of the income distribution scale and are preferentially taxed. ${ }^{2}$ In about one-half of OECD countries, capital gains made on shares are subject only to corporate income tax and not to personal income tax. In those countries where capital gains are subject to personal income tax, tax rates on capital gains on shares range from 12 percent in Belgium and 20 percent in the UK to slightly above 55 percent in Denmark and Greece. For its part, Canada relies more heavily on income taxes relative to consumption and payroll taxes, and taxes capital income more heavily than in many OECD countries, especially those that use dual income tax systems.

Several countries have abolished or decreased annual wealth taxes and inheritance taxes. Only four of the 35 OECD countries still tax wealth, while taxes on immovable property throughout the OECD represent a small percentage of overall taxation. Two decades ago, one-half of OECD member countries had some type of annual wealth tax, but many have discontinued it, for example, Austria and Denmark in 1995, Germany in 1997, Finland and Luxembourg in 2006, Sweden in 2007 and France in 2017. In those few nations that continue to have a wealth tax, its proceeds have decreased over time. The wealth-tax share of total tax revenues in 2015 was 3.6 percent in
Switzerland, 2 percent in Luxembourg, 1 percent in Norway and 0.3 percent in Spain, or from 0.2 percent to 1 percent of GDP (OECD 2018a). Saez and Zucman (2019) estimate that the Warren wealth tax would raise about 1 percent of GDP in revenues, roughly the same as in Switzerland. ${ }^{3}$

In this Commentary, we critically evaluate the case for an annual wealth tax as part of Canada's tax system. To do so, we review current received wisdom on the elements of a good tax system, drawing on the normative tax design literature and best practices. We do not address the issue of how responsive tax policy needs to be to deal with the evolving inequality of income and wealth. Our focus, instead, is on the mix of policy instruments that are most effective for whatever degree of responsiveness policymakers choose. Our argument is that wealth taxes add relatively little to the taxes on capital and capital income that are already in place, and that concerns about the social consequences of wealth concentration are better addressed by reform of existing capital income taxes and by considering wealth transfer (inheritance) taxation. ${ }^{4}$

Our argument against wealth taxation is over and above the substantial administrative challenges in measurement, collection and coverage for annual wealth taxes (OECD 2018b). These alone are enough to raise red flags about wealth taxation. For our part, we rely on the more fundamental argument that annual net wealth taxes are unnecessary since their objectives can be better

2 This can be misleading. Thivierge and Laurin (2017) show that the top 10 percent of Canadian families, when measured by average adult income, possess 86 percent of all taxable capital gains while the bottom 27 percent receive only 1 percent. However, when households are classified by employment income, the top 29 percent receive only 37 percent of capital gains compared with 25 percent for the bottom 29 percent.

3 More than half of the OECD member countries have some kind of wealth transfer tax. However, the revenues are low for most of them. The only countries for which wealth transfer tax revenues exceed 0.2 percent of GDP are Belgium (0.7), France (0.6), Japan (0.4), the Netherlands (0.3) and Korea (0.3). See https://stats.oecd.org/Index.aspx? DataSetCode=RS GBL.

4 This is consistent with views found in the survey papers by Boadway, Chamberlain and Emmerson (2010) and Kopczuk (2013). 
achieved by suitably designed taxes on capital income and wealth transfers.

\section{Wealth TAXation In PRACTICE}

Taxes on wealth and wealth transfers can take different forms. A wealth tax typically applies to net wealth; that is, assets less liabilities. It can be levied annually or as a one-off capital levy and typically varies with the level of personal wealth. Related to a wealth tax is the property tax, which is levied annually on the value of real property and typically at proportional rates. Property taxes are commonly used to finance local government, and rates vary by locality. Taxes on the value of capital are sometimes applied to corporations as an adjunct to the corporate income tax.

Taxes may also apply on wealth transfers. Taxes on transfers of wealth on death can take the form either of an estate tax levied on the estate's total value or of an inheritance tax levied separately on the amount of inheritance received by each recipient. Estate and inheritance taxes are levied on lifetime accumulations of wealth and apply, once only, either on death or within a prescribed number of years prior to death. Probate fees often apply when estates are transferred to heirs, nominally to offset administration costs incurred by the state. There may also be gift taxes levied on donors or recipients when the gifts are made during the lifetime of either. Taxes may also apply on wealth transactions, such as land transfer taxes on the sale of property or stamp duties on the sale of financial assets. Some wealth transfers are subsidized, such as donations to charities, nonprofits and political parties.

Occasionally, countries have used a one-off tax on private wealth as an exceptional measure to restore debt sustainability. To be effective, such a tax has to be implemented before avoidance is possible and with the expectation that it will not be repeated. Only in these circumstances does it not distort behaviour. Such a one-off wealth tax is seen by some as fair, despite the fact that it amounts to an unannounced confiscation of wealth. That is because it is applied only in unusual circumstances of financial stringency, or when wealth holders might be thought to have gained disproportionately while others suffered.

The use of wealth and wealth transfer taxes in Canada is limited. There is no tax on inheritances, estates or gifts, though most provinces charge relatively small probate fees. ${ }^{5}$ Accrued capital gains are deemed realized and taxed as capital gains on death, but this is simply a prepayment of capital gains tax that would otherwise have been taxed on realization. Residential and business property taxes are applied in all provinces, sometimes by municipal governments only, and sometimes by the province. Meanwhile, eight provinces deploy provincial business property taxes. Their intent is to finance local and provincial public services rather than to achieve redistribution.

Land transfer taxes also apply in all provinces and in some municipalities. The federal government and some provinces apply taxes on the capital of large financial institutions and life insurance companies, although these taxes have been diminishing and have been repealed in many jurisdictions. Overall, the use of wealth and wealth transfer taxes in Canada is limited relative to other OECD countries, and they play almost no role in redistribution.

Capital income is subject to income tax, but with significant exceptions. Savings for retirement through Registered Pension Plans (RPPs), Registered Retirement Savings Plans (RRSPs) and Tax Free Savings Accounts (TFSAs) shelter a significant proportion of capital income, especially for low-income persons. Only one-half of capital

5 For example, Ontario's estate administration tax is 1.5 percent of estates larger than $\$ 50,000$. 
gains are taxable and dividends from Canadian corporations receive a dividend tax credit, which represent substantial tax benefits to Canadian savers. ${ }^{6}$ Also, imputed income, including capital gains, on owner-occupied housing and other consumer durables is tax-exempt. Corporations do pay tax on shareholder income, but recent estimates suggest that at least half of corporate taxes are shifted to labour. (See Zodrow 2010, Arulampalam, Devereux and Maffini 2012, Azémar and Hubbard 2015, McKenzie and Ferede 2017, Fuest, Peichl and Siegloch 2018.) When combined with the implicit sheltering of capital income through the Goods and Services Tax (GST), the Canadian tax system treats capital income quite favourably.

\section{CAPITAL INCOME TAXATION AS COMPONENT OF THE TAX SYSTEM}

As mentioned, an annual wealth tax is one of a family of taxes that can be applied to asset wealth or its return, others being capital income taxes, business income taxes, wealth transfer taxes and annual taxes on real property. These taxes exist alongside the GST on consumption and payroll taxes on labour income. Countries adopt different mixes of tax bases, but virtually all use hybrid systems combining features of two benchmark systems. One is comprehensive income taxation, which forms the basis for Canadian income tax legislation and under which the tax base is the sum of consumption and net changes in wealth or net savings. The second benchmark tax system is based on consumption itself, which can be taxed either directly through personal taxation or indirectly by taxes on consumption transactions.

Neither comprehensive income nor personal consumption are readily observed by the Canada Revenue Agency, but both can be indirectly measured using equivalent tax bases in presentvalue terms. Using the consumer's lifetime budget constraint, the comprehensive income tax base is equivalent in present-value terms to the sum of labour income, capital income and inheritances. By the same token, the consumption base is equivalent in present-value terms to the sum of labour income, inheritances and other transfers, and that part of capital income reflecting windfall, or unexpected, gains. ${ }^{7}$ It will be useful to fit the discussion of annual wealth taxes into this framework of the mix of tax bases.

To appreciate the potential for wealth taxes to be a component of hybrid income-consumption tax systems, it is useful to recount how various elements of standard tax bases contribute to the comprehensive income versus consumption balance. Consumption can be taxed explicitly and indirectly by a broad, destination-based valueadded tax such as the GST, although this approach precludes progressive rate structures. Alternatively,

6 The dividend tax credit and the capital gains exemption are instruments for integrating the personal and corporate tax systems to avoid double taxation. Boadway and Tremblay (2016) argue that integration is not warranted because much of the corporate tax is not borne by shareholders and because much corporate-source income is sheltered at the personal level.

7 To see this in formulaic terms, consider the two time-periods' case where an individual earns $E_{1}$ and $E_{2}$ and receives an inheritance or other transfer $I$ in the first period. The budget constraints in each period are $C_{1}=E_{1}+1-S$ and $C_{2}=E_{2}+(1+r) S+\rho \bar{S}$, where $C_{i}$ is period-i consumption (including bequests given), $S$ is saving, $r$ is the interest rate, and $\rho \bar{S}$ is above-normal returns accruing on a portion of savings $\bar{S}<S$. Eliminating $S$ from the two budget constraints yields the intertemporal budget constraint:

$$
C_{1}+\frac{C_{2}}{1+r}=E_{1}+I+\frac{E_{2}}{1+r}+\frac{\rho \bar{S}}{1+r} .
$$


consumption can be taxed under the personal tax system, using one of two approaches. Consumption expenditures can be taxed directly and progressively by a personal base defined as income (including labour and capital income and inheritances) less savings. This is the tax-deferred approach and is roughly the way in which private pensions like RPPs and RRSPs are treated.

The alternative form of taxing consumption is the tax-prepaid approach where the base includes labour income and inheritances, or total income less capital income. The TFSA takes the tax-prepaid approach, as does the taxation of owner-occupied housing and other consumer durables. This approach captures consumption imperfectly to the extent that capital income includes windfall gains such as unexpected returns ${ }^{8}$ or rents from monopoly and other circumstances - that ought to be part of the tax base. Note that hybrid consumptionincome tax systems, like that of Canada, may treat different forms of capital income very differently. Indeed, RRSPs, RPPs and TFSAs have different contribution limits.

Some forms of asset income are not taxsheltered, such as personal business assets, and some are fully tax-sheltered, such as consumer durables. As discussed below, this leaves scope for tax reform to justify the argument that capital taxation renders wealth taxation redundant.

The UK Mirrlees Review (2011), whose mandate was to identify the qualities of a fair and efficient tax system, proposed a variant of the tax-prepaid approach to take account of the fact that returns to some assets, particularly those in large portfolios, could be above normal. For savings in assets other than interest-bearing accounts and pensions, only returns up to a risk-free rate-of-return allowance (RRA) would be tax-exempt, while returns above that - including both rents and returns to risk would be fully taxed. This would ensure that the RRA approach is equivalent to the tax-deferred approach and that consumption financed by abovenormal returns to capital, such as monopoly rents and unexpected or windfall gains, is fully taxed. To the extent that above-normal returns accrue to higher-income taxpayers, taxation equity might be improved. In fact, since the tax-deferred approach accomplishes much the same as this RRA approach, it is not clear that much is gained by the latter. ${ }^{9}$

Actual tax systems do not include all consumption in the tax base, regardless of whether they aim to tax income or consumption. The GST/ HST system either exempts or zero-rates some types of consumption, such as food and other necessities. Taxation of assets that rely on the tax-prepaid approach, such as TFSAs or housing, does not include consumption financed from above-normal returns. Personal tax bases do not include consumption financed from inheritances to the extent that, as in Canada, the latter are not themselves taxed. They do however implicitly tax bequests, since these are included in expenditures from taxpayer income. In countries where inheritances are taxed, they are usually only partially taxed and are taxed more favourably than ordinary income. High exemption levels apply, and some forms of wealth transfers, such as farms and family businesses, are typically exempt. On the other

8 Economic rents are profits in excess of normal competitive profits. More technically, rents in a given period are the difference between a firm's revenues and the opportunity costs of all inputs, including the manager's or entrepreneur's time and risk-taking. Rents are notoriously difficult to measure since the imputed costs of some inputs are not directly observable. However, a cash-flow tax or its present-value equivalent approximates the current value of economic rents under normal economic conditions (Boadway and Tremblay 2016).

9 The Mirrlees Review recognized that returns to risk would be taxed under both the RRA and tax-deferred approaches, but it argued that as long as there was full loss-offsetting, risk taking would not be discouraged. 
hand, housing is often included in inheritance tax bases. In the few countries having annual wealth taxes, these are typically in lieu of an inheritance tax, despite the fact that they fulfil very different functions.

While Canada does not have an inheritance tax, capital gains tax applies to accrued capital gains on inheritances since these are deemed to be realized on death. As mentioned, this approach simply taxes capital gains on death that would otherwise be postponed until realization actually occurs. Since the cost base of inherited assets is the value deemed to be realized at death, heirs are subject only to tax on gains that have accrued since the inheritance is received. However, deemed realization is not a substitute for inheritance taxation since it applies only to income that would eventually be liable for capital income tax. The imposition of an inheritance tax need not entail a change in the deemed realization of capital gains on inheritances at death.

There are many reasons for taxing capital income more favourably than labour income or consumption and why some forms of capital income are exempt. On theoretical grounds, some taxation of capital income can be justified as an efficient way of redistributing from better-off to worse-off individuals (Banks and Diamond 2010). In addition, taxing capital income has been justified as a way of addressing the inefficiencies associated with the absence of wage insurance and with credit constraints (Conesa et al. 2009). Typically, these arguments would support capital income taxation at lower rates than labour income taxation and with rates that are higher for high-income persons.

At the same time, capital income tax rates are constrained by the possibility of avoidance through tax planning or capital flight. Some types of asset income, such as from human capital investment ${ }^{10}$ and housing for which imputed income is hard to measure, are difficult to tax from an administrative point of view. As well, some assets are tax-sheltered for policy reasons, like saving for retirement, whose encouragement is warranted on behavioural grounds. Preferential treatment of investments by entrepreneurs and small businesses is a response to the high risk of failure and limited access to capital markets many face. It is important to note that the mix of GST and income taxation automatically results in the preferential treatment of capital income.

Strong arguments also support applying an inheritance tax as a complement to consumption, labour income and capital income taxation, regardless of the extent to which capital income is taxed. From the recipients' point of view, inheritances represent a windfall gain that can be used to finance consumption over their lifetimes. Regardless of whether the personal tax system is based on consumption tax or comprehensive income tax principles, taxing consumption is an element. To the extent that consumption is taxed explicitly, taxing inheritances that finance that consumption would be redundant. For example, the GST taxes consumption expenditures regardless of how they are financed.

On the other hand, taxing consumption at the personal level by using either the tax-prepaid approach or the tax-deferred approach would require that inheritances be taxed. Recall that the tax-prepaid approach exempts capital income from the base and would be equivalent to consumption taxation only if all forms of non-capital income, including labour income, transfers and inheritances, are in the base. Similarly, under tax-deferred treatment, the tax base is income less savings, where income includes labour and capital income, transfers and inheritances. If the tax base is income

10 Human capital is the present value of the future earning capacity of an individual. Earning capacity can be augmented by investment in education or training, and it depreciates through obsolescence of skills and by aging which reduces the number of remaining years of work. 
rather than consumption, the same principles require including inheritances in the base since they are equivalent to income. Naturally, in choosing tax rates one must take into account behavioural responses, such as changes in labour supply, savings and, in the case of inheritance taxation, changes in bequests, but the choice of the tax base is separate from these considerations.

\section{WEALTH TAXATION AS PART OF THE TAX MIX}

An annual wealth tax would add one more layer of asset taxation to the existing patchwork of capital income, labour income, consumption and property taxes. In principle, annual wealth taxation is analogous to the taxation of income from that wealth, depending on how it is designed. To the extent that income from wealth is proportional to the stock of wealth, taxing wealth directly is equivalent to taxing the capital income from that wealth, as discussed in more detail below. However, there are some differences. If wealth taxation were based on the market value of wealth, which is the expected present value of future returns, possibly adjusted for risk, a capital income base would be more variable than a wealth base. Moreover, capital income taxation would tax unexpected, or windfall, gains whereas a wealth tax would not. That is, the value of wealth is the present value of expected future returns.

Any one-off unexpected or windfall gains would not affect the value of wealth so would not be subject to wealth tax. Where returns to wealth take an imputed form, taxing wealth itself might be much simpler than taxing the returns. This may be the case for housing and for valuables that yield an intrinsic return. On the other hand, some forms of wealth, such as human wealth that either has been endowed in the individual or has been accumulated, are inherently more difficult to measure than the income streams to which they give rise.

Two further points can be made about wealth taxation versus other forms of asset taxation before analyzing the case for and against it. First, some might argue that wealth per se should be taxed because of the benefit it generates for its owners. This may be an intrinsic benefit, such as the prestige and status associated with being seen to be wealthy. Alternatively, wealth may confer power and influence to wealth owners with substantial holdings. Basing a tax on wealth on its contribution to power and prestige would go beyond standard utilitarian arguments. If the wealth had been accumulated from above-normal returns due to windfall gains or monopoly rents, taxing them ex post might be justified to the extent that the tax system did not tax them as they were earned, regardless of the power and prestige to which they give rise. To the extent that these considerations are true, they would reinforce the case for progressive wealth taxation.

Second, while wealth taxation is analogous to the taxation of the returns on wealth, it differs from bequest or inheritance taxation. Bequests represent a cumulative accrual of wealth over a lifetime, while inheritances represent windfall receipts at some point in one's lifetime. In contrast, wealth taxation is a recurring annual tax on wealth over a life cycle. A wealth tax applies to saving done partly for life-cycle smoothing purposes, while a bequest tax applies to wealth accumulated over and above that used for life-cycle smoothing, and an inheritance tax applies to windfall increases in wealth. Even if one did not want to tax capital income or capital itself - for example, if the tax system aimed to tax consumption - one might still want to tax inheritances. This would be the case to the extent that consumption is taxed on the income or source side of a taxpayers' budget rather than directly, since the budgetary source of consumption finance comes from both labour income and inheritances.

\section{THE ECONOMIC ARGUMENTS FOR - AND AGAINST - WEALTH TAXATION}

Let us probe in more detail the case for including an annual wealth tax as part of the tax system. 
The arguments are heavily influenced by the similarities between taxing wealth and taxing capital income. Under certain conditions, these two forms of taxation are effectively identical. Suppose an individual has wealth consisting of a fully owned house and a portfolio of stocks. Suppose, furthermore, that the tax on capital income includes both the imputed income of the home and the dividends plus the accrued capital gains of the stocks. Suppose, finally, that these capital incomes are such that their present value is equal to the value of the wealth to be taxed and that both taxes are flat rate. Under these assumptions, the two types of levy are equivalent.

In practice, this is far from the case for many reasons. The two taxes may not have the same base: some assets are exempt from the wealth tax and others from the capital income tax. Taxes on capital gains may be preferential and apply only on realization. A wealth tax will cover accrued capital gains, assuming the value of assets is properly assessed. On the other hand, there can be a large discrepancy between the market value of a dwelling and its assessed value. Also, the tax rates differ in level and progressivity, and in the exemption level. In regard to the differing tax bases, the annual wealth tax base typically includes housing, net of debts, deposits, financial assets and valuables, but not business assets. This is much different from the usual capital income taxes, which include personal business income but not imputed income from housing.

Another difference between wealth and capital income taxes is often advanced. It concerns liquidity. Persons with considerable wealth but a small income may be unable to pay the annual tax. In Germany, a court held that the sum of wealth tax and income tax must not exceed one-half of a taxpayer's income. Eventually the courts declared the wealth tax unconstitutional because of its confiscatory nature.

A wealth tax can be viewed as a supplement to capital income taxation where the latter is imperfect. For some types of assets, the rate of return might be difficult to measure. Examples include owner-occupied housing, automobiles and other consumer durables, personal valuables and cash. A wealth tax that targeted these assets could complement capital income taxation, although valuation and compliance problems would be challenging. For other assets, both the rate of return and the asset value might be difficult to measure. An important example of this is human capital investment that results in higher earnings. Its return can be implicitly taxed if the income tax system is progressive, but otherwise human capital tends to be a tax-sheltered asset since it is taxed roughly on a cash-flow basis analogous to tax-deferred assets. ${ }^{11}$

Personal businesses yielding capital income are challenging to measure, but measuring their asset value is no less difficult, especially for intangible assets. More generally, capital income earned on behalf of shareholders by corporations can be taxed using a corporate income tax although, as mentioned, much of the tax is shifted to labour. Arguably, it would be easier to tax corporate-source income using a wealth tax. The latter would apply to the value of corporate stocks held by taxpayers directly with no need for a corporate tax at all.

Overall, the case for implementing a wealth tax as a complementary way of taxing capital income is limited. The argument is strongest for assets like housing and other durables whose returns are difficult to measure and for corporate stocks whose returns can be sheltered within the corporation. In the case of housing and some business assets, the property tax already applies to them.

11 That is, earnings resulting from human capital investment are taxed as they are obtained, while forgone earnings - which are the most significant cost - are implicitly deductible. 
At the same time, there are significant drawbacks to wealth taxation relative to capital income taxation. An important one is that a tax on capital income includes windfall gains in the tax base while a wealth tax does not. The value of wealth reflects expected returns, and these do not change if there is a windfall gain. Such a gain is by definition unexpected and, since it is non-recurring, does not affect the value of wealth. Given that the taxation of windfall gains is highly desirable, this is a significant drawback to a wealth tax. By the same token, a tax on capital income will apply to returns to risk, while a wealth tax will not. As long as there is lossoffsetting in the income tax system, this should not be a significant drawback to capital income taxation. Indeed, in some circumstances taxing returns to risk can be a valuable form of insurance that increases risk-taking (Domar and Musgrave 1944, Stiglitz 1969, Buchholz and Konrad 2014).

Capital income taxes also have some flexibility advantages from a tax design point of view. They can have exemption levels, as in France and the UK. In addition, some forms of capital income are tax-sheltered, and these tax-sheltered savings can have an upper limit that restricts their availability to high-income persons. A capital income tax can be designed so that it applies only to abovenormal earnings, as in the case of RRA taxation proposed by the Mirrlees Review mentioned above, or equivalently tax-deferred tax treatment. While capital income tax may not apply to certain asset returns, like housing, it can be augmented by property taxation or by the taxation of housing capital gains. Finally, under a dual income tax such as is used in Nordic countries, a proportional tax rate is applied to capital income alongside a progressive earnings tax. This makes evasion more difficult than ordinary income taxation since financial intermediaries can be used to withhold tax. These aspects may be difficult to replicate using wealth taxation.

The upshot of this discussion is that a wealth tax is to a large extent an imperfect substitute for a tax on capital income. It has the advantage that it can tax assets whose return is difficult to measure for income tax purposes, especially consumer durables. At the same time, it is inferior to capital income taxation when rates of return are easier to measure than asset values, such as intangible assets, intellectual and knowledge property and personal businesses. And it has the significant disadvantage that it does not tax windfall gains. Moreover, it is no better than capital income taxation for taxing human capital returns and inheritances at rates reflecting their advantage to inheritors.

While capital income taxation can render wealth taxation redundant, its full advantages can be achieved only if it is well designed. The existing system of capital income taxation treats very differently various forms of capital income such as imputed income on housing, tax sheltering, capital gains versus other forms of capital income and windfall gains. Various authors have proposed reform to capital income taxation to rationalize its structure and to ensure that windfall gains are subject to taxation, regardless of the extent to which normal capital income is taxed. Some have advocated taxing capital gains on owner-occupied housing beyond some threshold or making property taxes progressive (Kershaw 1997, Boadway 2015, Kesselman 2016). Others have proposed broadening the capital income tax base by reducing the capital gains exemption or restricting tax sheltering using TFSAs (Spiro 2017, Kesselman 2017, Boadway 2019). Other suggestions include moving to a dual income tax system (Milligan 2014) and exploring an inheritance tax (Boadway 2019).

\section{CONCLUSIONS}

Wealth and capital income taxes are analogous and fulfil similar functions. The ultimate rationale for taxing wealth is the same as for taxing capital income, and we have recounted the arguments underlying this rationale. Given that, the case for an annual wealth tax rests primarily on the shortcomings of capital income taxation. There may be some assets, such as housing and other 
consumer durables, for which the returns are difficult to measure. An annual tax on the value of such assets could be a useful complement to capital income taxation. That must be weighed against the administrative and compliance costs of such taxes, which could be substantial (OECD 2018a). In practice, annual taxes on housing values are frequently used as instruments for financing local government. Given that, the case for taxing the imputed income of housing is reduced.

Our judgment is that a well-functioning capital income tax is far superior to an annual wealth tax. The benefit of implementing the latter alongside a capital income tax does not compensate for the significant administrative costs that would be involved. However, this judgment comes with some caveats. The case for relying solely on capital income taxation (along with labour and consumption taxation) is strongest when the capital income tax includes all forms of capital income including capital gains. That is not to say that the rate of taxes applied to capital income should be the same as those applying to labour income. A dual income tax system with a uniform rate applied to all forms of capital income and independent of the taxpayer's income level, has significant administrative advantages, though at the expense of progressivity. At the same time, taxing housing wealth using a property tax rather than taxing imputed rent (i.e., the income that would have been obtained from renting out the housing) makes good sense, especially since property taxation is a wellestablished tax for financing local government. 


\section{REFERENCES}

Arulampalam, Wiji, Michael Devereux, and Giorgia Maffini. 2012. "The Direct Incidence of Corporation Tax on Wages." European Economic Review 56: 1038-1054. August.

Azémar, Céline, and R. Glenn Hubbard. 2015. "Country Characteristics and the Incidence of Capital Income Taxation on Wages: An Empirical Assessment." Canadian Journal of Economics 48: 1762-1802. December.

Banks, James, and Peter Diamond. 2010. "The Base for Direct Taxation.” in J. Mirrlees et al. (eds.), Dimensions of Tax Design. Oxford: Oxford University Press, pp. 548-648.

Boadway, Robin. 2015. "Tax Policy for a Rent-Rich Economy." Canadian Public Policy 41: 253-64. December.

Boadway, Robin, Emma Chamberlain and Carl Emmerson. 2010. "Taxation of Wealth and Wealth Transfers." in J. Mirrlees et al. (eds.). Dimensions of Tax Design. Oxford: Oxford University Press, pp. 737-814.

Boadway, Robin, and Jean-François Tremblay. 2016. Modernizing Business Taxation. Commentary 452. Toronto: C.D. Howe Institute. .2019. "Rationalizing the Canadian Tax System.” Canadian Tax Journal. Forthcoming.

Boadway, Robin, and Pierre Pestieau. 2018. "The Tenuous Case for an Annual Wealth Tax.” IEB Working Paper 2018/01. Barcelona: Institut d'Economia de Barcelona.

Buchholz, Wolfgang, and Kai A. Konrad. 2014. "Taxes on Risky Returns - an Update.” Max Planck Institute for Tax Law and Public Finance Working Paper 2014-10. Munich.

Conesa, Juan Carlos, Sagiri Kitao, and Dirk Krueger. 2009. "Taxing Capital? Not a Bad Idea after all." American Economic Review 99: 25-48. March.

Diamond, Peter. 2006. “Optimal Tax Treatment of Private Contributions for Public Goods with and without Warm Glow Preferences." Journal of Public Economics 90: 897-919. May.
Domar, Evsey D., and Richard Musgrave. 1944.

"Proportional Income Taxation and Risk-taking." Quarterly Journal of Economics 58: 388-422. January.

Fagereng, Andreas et. al. 2016. "Heterogeneity and Persistence in Returns to Wealth.” NBER Working Paper w22822. Cambridge, MA.: National Bureau of Economic Research.

Frenette, Marc, David Green and Kevin Milligan. 2007. "The Tale of the Tails: Canadian Income Inequality in the 1980s and 1990s." Canadian Journal of Economics 40(3): 734-64. August.

Fuest, Clemens, Andreas Peichl, and Sebastian Siegloch. 2018. "Do Higher Corporate Taxes Reduce Wages? Micro Evidence from Germany." American Economic Review 108: 393-418. February.

Kacperczyk, Marcin, Stijn Van Nieuwerburgh, and Laura Veldkamp. 2016. "A Rational Theory of Mutual Funds' Attention Allocation.” Econometrica 84: 571-626. March.

Kershaw, Paul. 1997. "A Tax Shift - The Case for Rebalancing the Tax Treatment of Earnings and Housing Wealth.” Canadian Tax Journal 66(3): 585604. October.

Kesselman, Jonathan Rhys. 2016. "Attacking High Housing Prices by Making Property Taxes Progressive.” Intelligence Memo. Toronto: C.D. Howe Institute. 2017. "Toward a Broader Base for Personal Taxation: Reconciling Equity with Efficiency." In Jinyan Li, J. Scott Wilkie and Larry F. Chapman (eds.). Income Taxation at 100 Years: Essays and Reflections on the Income Tax War Act. Toronto: Canadian Tax Foundation 6:1-40.

Kopczuk, Wojciech. 2013. "Taxation of Intergenerational Transfers and Wealth.” In Alan J. Auerbach et al. (eds.). Handbook of Public Economics, Volume 5. Amsterdam: North Holland, pp. 329-390.

Larrimore, Jeff et al. 2017. "Recent Trends in U.S. Top Income Shares in Tax Record Data Using More Comprehensive Measures of Income Including Accrued Capital Gains." NBER Working Paper 23007. Cambridge, MA. 
McKenzie, Kenneth J., and Ergete Ferede. 2017.

"Who Pays the Corporate Tax?: Insights from the Literature and Evidence for Canadian Provinces." The School of Public Policy. Research Paper 10 (11). University of Calgary.

Milligan, Kevin. 2014. “Tax Policy for a New Era: Promoting Economic Growth and Fairness." Benefactors Lecture, 2014. Toronto: C.D. Howe Institute.

Mirrlees, James, et al. 2011. Tax by Design (The Mirrlees Review). Oxford: Oxford University Press.

Organisation for Economic Cooperation and Development. 2018a. The Role and Design of Net Wealth Taxes in the OECD. Paris: OECD. . 2018b. "Inequalities in Household Wealth across OECD Countries: Evidence from the OECD Wealth Distribution Database."Working Paper No.88. Paris: OECD.

Piketty, Thomas. 2013. Capital in the Twenty-First Century. Paris: Éditions du Seuil.

Piketty, Thomas, and Emmanuel Saez. 2003. "Income Inequality in the United States, 1913-1998.” Quarterly Journal of Economics 118(1):1-39. February.
Saez, Emmanuel, and Gabriel Zucman. 2019. "How Would a Progressive Wealth Tax Work? Evidence from the Economics Literature." University of California at Berkeley. Mimeo. February.

Spiro, Peter S. 2017. Tax Incentives for Investment Income: Boon or Bane? Mowat Research \#143. Toronto: Mowat Centre.

Stiglitz, Joseph E. 1969. "The Effects of Income, Wealth, and Capital Gains Taxation on Risk-Taking." Quarterly Journal of Economics 83: 263-83. May.

Thivierge, Vincent, and Alex Laurin. 2017. "Capital Gains Widely Enjoyed, Not Just by Top Earners.” Intelligence Memo. Toronto: C.D. Howe Institute.

World Inequality Lab. 2018. World Inequality Report 2018. Coordinated by F. Alvaredo et al. Paris.

Zucman, Gabriel. 2019. "Global Wealth Inequality." Annual Review of Economics 11, forthcoming.

Zodrow, Georges R. 2010. "Capital Mobility and Capital Tax Competition.” National Tax Journal 63: 865-902. December. 
NOTES: 
NOTES: 
NOTES: 


\section{ReCent C.D. Howe institute Publications}

June 2019 Robson, William B.P., and Farah Omran. "Show and Tell: Rating the Fiscal Accountability of Canada's Senior Governments, 2019.” C.D. Howe Institute Commentary 545.

June 2019 Wyonch, Rosalie, and William B.P. Robson. "Filling the Gaps: A Prescription for Universal Pharmacare.” C.D. Howe Institute Commentary 544.

May 2019 Schwanen, Daniel, Jeremy Kronick, and Farah Omran. "Growth Surge: How Private Equity Can Scale Up Firms and the Economy.” C.D. Howe Institute E-Brief.

May 2019 Brown, Robert L., and Stephen A. Eadie. “The Great Pension Debate: Finding Common Ground.” C.D. Howe Institute Commentary 543.

May 2019 Miller, Eric. "Branching Out: How Canada’s Forestry Products Sector is Reshaping its Future.” C.D. Howe Institute Commentary 542.

May 2019 Comeau, Kevin. "Why We Fail to Catch Money Launderers 99.9 percent of the Time.” C.D. Howe Institute E-Brief.

April 2019 Robson, William B.P. “Healthcare Spending Overshoots a Threat to Sustainability.” C.D. Howe Institute E-Brief.

April 2019 Bishop, Grant. "Moving the Coal-posts: Ottawa's Wrong Turn on Carbon Pricing for Electricity Generation.” C.D. Howe Institute E-Brief.

April 2019 Trebilcock, Michael J., and Kanksha Mahadevia Ghimire. "Regulating Alternative Medicines: Disorder in the Borderlands.” C.D. Howe Institute Commentary 541.

April 2019 Murray, John D. “Central Banks and the Future of Money.” C.D. Howe Institute Commentary 540.

April 2019 Chaykowski, Richard P. “Time to Tweak or Re-boot? Assessing the Interest Arbitration Process in Canadian Industrial Relations.” C.D. Howe Institute Commentary 539.

March 2019 Baldwin, Bob. “The Evolving Wealth of Canadians Approaching Retirement.” C.D. Howe Institute Working Paper.

March 2019 Grace, Chuck. "Next Gen Financial Advice: Digital Innovation and Canada's Policymakers." C.D. Howe Institute Commentary 538.

\section{SUPPORT THE INSTITUTE}

For more information on supporting the C.D. Howe Institute's vital policy work, through charitable giving or membership, please go to www.cdhowe.org or call 416-865-1904. Learn more about the Institute's activities and how to make a donation at the same time. You will receive a tax receipt for your gift.

\section{A REPUTATION FOR INDEPENDENT, NONPARTISAN RESEARCH}

The C.D. Howe Institute's reputation for independent, reasoned and relevant public policy research of the highest quality is its chief asset, and underpins the credibility and effectiveness of its work. Independence and nonpartisanship are core Institute values that inform its approach to research, guide the actions of its professional staff and limit the types of financial contributions that the Institute will accept.

For our full Independence and Nonpartisanship Policy go to www.cdhowe.org. 

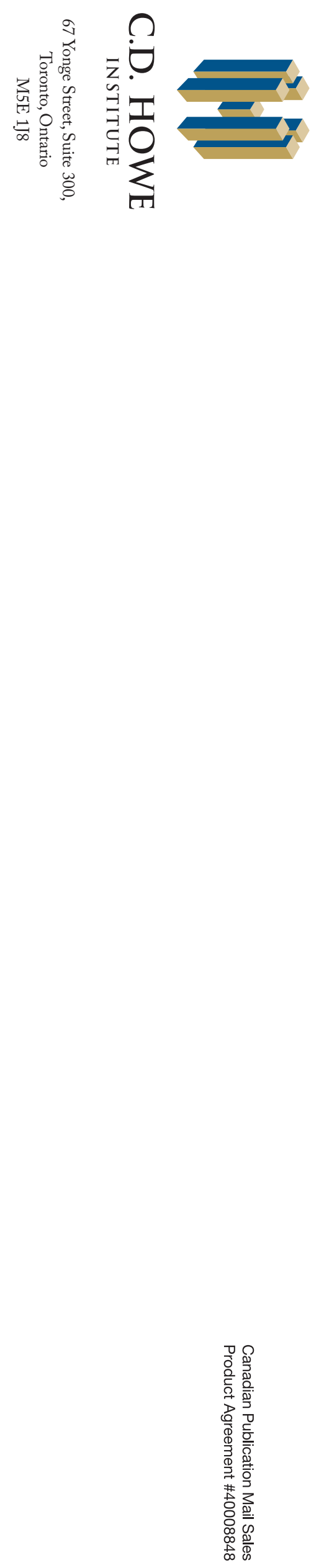